\title{
MANUAL INTRACARDIAC ELECTROGRAM METHOD IS ACCURATE ALTERNATIVE TO ECHOCARDIOGRAPHY FOR ATRIOVENTRICULAR AND INTERVENTRICULAR OPTIMIZATION IN CARDIAC RESYNCHRONIZATION THERAPY
}

\author{
Borka Pezo Nikolić ${ }^{1}$, Daniel Lovrić ${ }^{1}, J_{a n a}$ Ljubas Maček ${ }^{1}$, Vlatka Rešković Lukšić ${ }^{1}$, \\ Richard Matasić ${ }^{1}$ and Jadranka Šeparović Hanževački ${ }^{1,2}$ \\ ${ }^{1}$ Department of Cardiovascular Medicine, Zagreb University Hospital Centre, Zagreb, Croatia; \\ ${ }^{2}$ University of Zagreb, School of Medicine, Zagreb, Croatia
}

SUMMARY - Some manufacturers do not provide automated intracardiac electrogram method (IEGM) systems for atrioventricular (AV) and interventricular (VV) delay optimization in cardiac resynchronization therapy (CRT). We aimed to evaluate the accuracy of manual IEGM method in 48 patients previously implanted with Medtronic Syncra CRT. All patients underwent standard device interrogation followed by CRT optimization by IEGM method and by echocardiography one month after implantation. The patient mean age was $60.7 \pm 11.8$ years and there were $33(68.8 \%)$ males. After CRT implantation, the left ventricular ejection fraction increased from $28.0 \pm 7.9 \%$ to $39.1 \pm 11.0 \%$ $(\mathrm{p}<0.001)$. Optimal aortic flow Velocity Time Integral (aVTI) was obtained when VV was set to 20-50 ms left ventricular pre-activation. There was a strong correlation between $\mathrm{VV}$ values determined by echocardiography and IEGM $(\mathrm{R}=0.823, \mathrm{p}<0.001)$. We found no significant difference in $\mathrm{AV}, \mathrm{VV}$ and aVTI values between echocardiography and IEGM method. However, IEGM was significantly less time-consuming than echocardiography [20 (10-28) vs. 40 (35-60) minutes, $\mathrm{p}<0.001]$. Manual IEGM method may be good alternative to echocardiography and automated IEGM method. It also emphasizes the need for implementation of automated IEGM systems in as many CRT devices as possible.

Key words: Intracardiac electrogram; Optimization; Cardiac resynchronization therapy; Atrioventricular delay; Interventricular $V V$ delay

\section{Introduction}

In refractory congestive heart failure $(\mathrm{CHF}) \mathrm{ac}-$ companied by left bundle branch block (LBBB), cardiac resynchronization therapy (CRT) with biventricular pacing has been shown to be associated with better outcomes and has been established as an adjunctive heart failure treatment ${ }^{1-3}$. It has been shown in multicenter studies that CRT reduces mortality, and improves exercise tolerance and quality of life $\mathrm{f}^{4-6}$.

Correspondence to: Borka Pezo Nikolić, MD, Zagreb University Hospital Centre, Kišpatićeva 12, HR-10000 Zagreb, Croatia

E-mail: borkapezo@yahoo.com

Received June 30, 2017, accepted September 26, 2017
Sequential ventricular pacing can increase mechanical efficiency, decrease delay in contraction between adjacent left ventricular (LV) walls, reduce mitral regurgitation $^{7,8}$, and increase ejection fraction $(\mathrm{EF})$. However, up to $30 \%$ of patients who underwent CRT implantation show no improvement. The reasons for failure to respond include suboptimal lead placement, device programming and/or patient selection. Atrioventricular $(\mathrm{AV})$ delay also has a significant effect on the hemodynamic performance of cardiac pacing since insufficient LV filling in diastole leads to a decline in cardiac output ${ }^{9}$. Optimizing the third parameter of dyssynchrony, the interventricular (VV) delay, with se- 
quential biventricular pacing compared to simultaneous biventricular pacing has also been shown to incrementally improve cardiac function ${ }^{7-12}$. AV/PV and VV delay optimization is not commonly performed in routine clinical practice despite being one of the programmable parameters available. Only those that do not show improvement from CRT undergo echocardiographic optimization of their AV and VV intervals due to the costs, time constraints, and skill and expertise required to perform accurately.

The intracardiac electrogram method (IEGM) has been designed to calculate optimal AV/PV and VV delays during routine device follow-up ${ }^{1}$. Several studies have reported diagnostic accuracy of IEGM performed by using the software provided along with St. Jude's devices ${ }^{1,13,14}$. Such automated IEGM yielded similar results as echocardiography for AV and VV optimization. However, some CRT device manufacturers do not provide automated IEGM systems for AV and VV optimization.

The aim of this study was to evaluate diagnostic accuracy of manual application of IEGM formula used by St. Jude's devices in patients undergoing CRT with Medtronic devices and to evaluate whether the IEGM of AV/PV and VV delay optimization would produce similar hemodynamic results as assessed by aortic VTI as a surrogate for stroke volume compared with the standard Doppler echocardiogram technique.

\section{Patients and Methods}

\section{Patients}

We included 48 patients previously implanted with Medtronic Syncra CRT-P cardiac resynchronization therapy devices. All patients at our institution who fulfilled the standard indications for CRT according to ESC guidelines at the time of inclusion ${ }^{15}$ were invited to participate in this prospective study, which was approved by the local research Ethics Committee. $\mathrm{Pa}$ tients were excluded from IEGM studies if they had no intrinsic atrial activity (atrial rate $\leq 40 \mathrm{bpm}$ ); had atrial fibrillation at the time of the study testing and evaluation; or were unable to provide analyzable echocardiogram images. One month after CRT implantation, all patients underwent standard device interrogation followed by optimization of the CRT pacemaker settings by IEGM and by echocardiography (ECHO). The study was performed during a single scheduled follow up visit. All patients were first programmed, utilizing the IEGM, and after that, all patients underwent ECHO optimization. The investigator performing the ECHO study was blinded to the results of the IEGM evaluation.

The study was approved by the institutional Review Board. Considering human and animal rights, all procedures followed were in accordance with the ethical standards of the responsible committee on human experimentation (institutional and national) and with the Helsinki Declaration of 1975, as revised in 2008.

\section{Methods}

\section{Cardiac resynchronization therapy optimization using intracardiac electrogram method}

Calculation of the optimal sensed AV interval is based on atrial intrinsic depolarization (atrial IEGM). The atrial IEGM (P-wave duration) represents atrial conduction time and enables estimation of mitral valve closure. The algorithm measures the width of the atrial IEGM, which is off-set by a factor of $30 \mathrm{~ms}$ if the intrinsic depolarization is $>100 \mathrm{~ms}$, or $60 \mathrm{~ms}$ if the intrinsic depolarization is $<100 \mathrm{~ms}$. The off-set enables delivery of ventricular pacing after completion of atrial mechanical contraction ensuring complete mitral valve closure and maximizing preload. The optimal paced $\mathrm{AV}$ delay is calculated as the sum of sensed AV delay and the pacing latency of $40 \mathrm{~ms}^{16}$.

The IEGM VV delay calculation algorithm is based on the hypothesis that during optimal depolarization, two paced wavefronts from the RV and LV leads will meet near the interventricular septum. The VV delay algorithm has two components: the conduction delay $(\Delta)$ and the correction term $(\varepsilon)(1) . \Delta$ represents difference between the time of peak intrinsic activation on the $\mathrm{LV}$ lead $\left(\mathrm{R}_{\mathrm{LV}}\right)$ and the RV lead $\left(\mathrm{R}_{\mathrm{RV}}\right)[\Delta$ $\left.\mathrm{R}_{\mathrm{LV}}-\mathrm{R}_{\mathrm{RV}}\right]$. $\varepsilon$ is difference in the inter-ventricular conduction delay (IVCD) between two ventricular paced propagation waveform time delays. The IVCD RL is the interventricular conduction delay when the $\mathrm{RV}$ lead is paced and the delay is sensed at the LV lead, while the IVCD LR is estimated when the LV lead is paced and the delay represents the time when the signal is sensed at the RV lead. Furthermore, each chamber is paced after a short AV delay to ensure no fusion 
occurs. The correction term equation is $\varepsilon=$ IVCD LR - IVCD RL. The IEGM optimal VV delay equals $0.5(\Delta+\varepsilon)$. If measured $\mathrm{VV}$ is more than 0 , the $\mathrm{LV}$ is activated first, and if $\mathrm{VV}$ is less than 0 , the $\mathrm{RV}$ is activated first. Previous studies showed promise for the IEGM since the predicted optimal VV delays were linearly correlated with echocardiographic aortic $\mathrm{VTI}^{1,17-19}$

\section{Cardiac resynchronization therapy optimization by echocardiography}

Atrioventricular optimization

Optimization of the AV and VV intervals was undertaken using Pulse Wave Doppler of the General Electric Vivid 7 ultrasound machine. The AV interval was optimized first since it has been shown to provide more hemodynamic benefit than adjusting the VV interval ${ }^{20}$. The mitral inflow velocity profile was obtained in apical four-chamber view at the level of mitral valve leaflet tips at the sweep speed of $100 \mathrm{~mm} / \mathrm{s}$. First measurements were taken with either a very long $(200 \mathrm{~ms})$ or very short $(60 \mathrm{~ms}) \mathrm{AV}$ interval and the duration of the mitral inflow velocity profile (EA duration) was measured in expiration. The AV interval was then adjusted in $10 \mathrm{~ms}$ decrements/increments, respectively, and the EA duration was measured for each AV interval. The optimal $A V$ interval was defined as the shortest $\mathrm{AV}$ interval that resulted in maximal EA duration, thus representing the longest LV filling time without truncating the A wave of mitral inflow by the onset of ventricular systole $\mathrm{e}^{21,22}$.

Interventricular interval optimization

The LV outflow tract (LVOT) Pulse Wave Doppler velocity profiles were measured in the apical fivechamber view at the sweep speed of $100 \mathrm{~mm} / \mathrm{s}$. The LVOT VTI was measured in expiration at each VV interval ranging from -40 to $+40 \mathrm{~ms}$ in $10 \mathrm{~ms}$ increments. Only if the optimal LVOT VTI was measured at a VV interval of -40 or $+40 \mathrm{~ms}$, further measurements of LVOT VTI were performed with $10 \mathrm{~ms}$ increments (i.e. at -50 or $+50 \mathrm{~ms}$ ). The optimal VV interval was defined as the VV interval with highest LVOT VTI (a surrogate measure of stroke volume and cardiac output). Inter-observer variability was eliminated by ensuring all measurements were performed by a single senior echocardiographer. Intra-patient variability was
Table 1. Characteristics of the study population (continuous variables expressed as mean \pm standard deviation and categorical variables expressed as number and percentage)

\begin{tabular}{|l|l|}
\hline Patient characteristic & \\
\hline Age (years) & $60.7 \pm 11.8$ \\
\hline Male gender, n (\%) & $33(68.8 \%)$ \\
\hline BMI & $27.7 \pm 3.4$ \\
\hline DM type 2, n (\%) & $17(35.4 \%)$ \\
\hline PAD, n (\%) & $7(14.6 \%)$ \\
\hline CRI, $\mathrm{n}(\%)$ & $7(14.6 \%)$ \\
\hline Therapy, n (\%) & \\
Furosemide & $43(89.6 \%)$ \\
Spironolactone & $35(72.9 \%)$ \\
ACE inhibitor & $46(95.8 \%)$ \\
Ca channel antagonists & $48(100 \%)$ \\
Beta-blockers & $45(93.8 \%)$ \\
Amiodarone & $20(41.7 \%)$ \\
Digitalis & $1(2.1 \%)$ \\
\hline NYHA status, $\mathrm{n}(\%)$ & \\
1 & $4(8.3 \%)$ \\
2 & $11(22.9 \%)$ \\
3 & $33(68.8 \%)$ \\
\hline Type of cardiomyopathy, $\mathrm{n}(\%)$ & \\
dilated & $35(72.9 \%)$ \\
ischemic & $10(20.8)$ \\
non-specified & $3(6.3 \%)$ \\
\hline LV ejection fraction (\%) & $28.0 \pm 7.9$ \\
\hline LVEDV (mL) & $241 \pm 84$ \\
\hline LVESV (mL) & $177 \pm 68$ \\
\hline QRS duration (ms) & $183.5 \pm 19.9$ \\
\hline Placement of RV electrode, $\mathrm{n}(\%)$ & \\
RVA & $46(95.8 \%)$ \\
RVS & $2(4.2 \%)$ \\
\hline Placement of LV electrode, $\mathrm{n}(\%)$ & \\
PLV & $35(72.9 \%)$ \\
MCV & $3(6.2 \%)$ \\
AIV & $9(18.8 \%)$ \\
PV & $1(2.1 \%)$ \\
\hline
\end{tabular}

$\mathrm{BMI}=$ body mass index; $\mathrm{DM}$ = diabetes mellitus; $\mathrm{PAD}=$ peripheral artery disease; $\mathrm{CRI}=$ chronic renal insufficiency; $\mathrm{LV}=$ left ventricle; LVEDV = left ventricular end-diastolic volume; LVEDS = left ventricular end-systolic volume; RVA = right ventricular apex; RVS = right ventricular septum; $\mathrm{PLV}=$ posterolateral vein; $\mathrm{MCV}=$ middle cardiac vein; $\mathrm{AIV}=$ anterior intracardiac vein $; \mathrm{PV}=$ posterior vein 


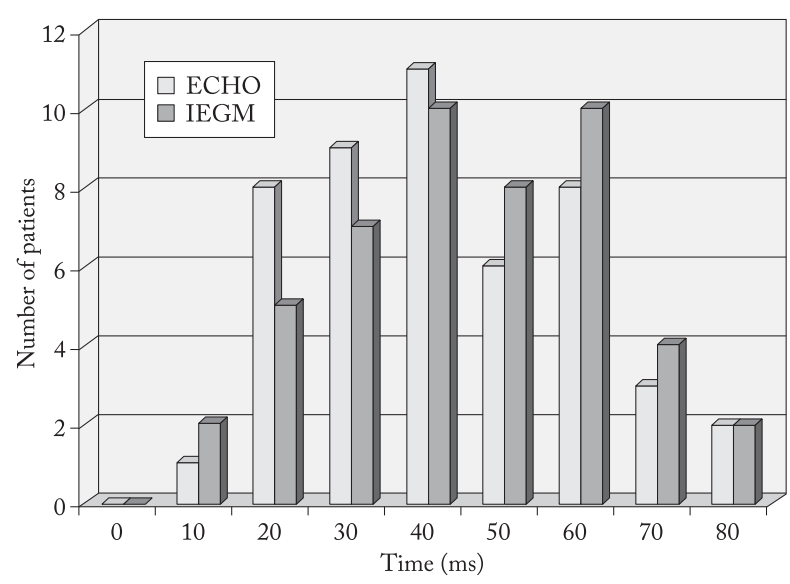

Fig. 1. Number of patients in each interventricular delay $(V V)$ interval determined by echocardiography (ECHO) and intracardiac electrogram method (IEGM).

minimized by ensuring measurements were performed at end-expiration and the mean of three consecutive measurements taken.

\section{Statistical analyses}

Patient characteristics were assessed with descriptive statistics presented as mean and standard deviation or median with interquartile range values. Independent variables were compared using the MannWhitney test and Fisher exact test, as appropriate. Dependent variables were compared using the Wilcoxon test. All correlations were performed using the Spearman's correlation coefficient. Sample size was calculated to be 45, when considering type 1 error (a) to be $5 \%$ and type 2 error (b) to be $20 \%$. Statistical analyses were performed using STATISTICA, ver. 6.0. The value of $p<0.05$ was considered significant.

\section{Results}

The mean patient age was $60.7 \pm 11.8$ years and there were $33(68.8 \%)$ males. The remaining characteristics of the study population are presented in Table 1. After CRT implantation, EF increased from $28.0 \pm 7.9 \%$ to $39.1 \pm 11.0 \%$, LVEDV decreased from $241 \pm 84 \mathrm{~mL}$ to $189 \pm 80 \mathrm{~mL}$, and LVESV decreased from $177 \pm 68 \mathrm{~mL}$ to $121 \pm 64 \mathrm{~mL}$ ( $\mathrm{p}<0.001$ all). Optimal aortic VTI was obtained when VV was set to 20$50 \mathrm{~ms}$ left ventricular pre-activation. The distribution of VV determined by echocardiography or IEGM was similar (Fig. 1). Moreover, we found no significant dif-

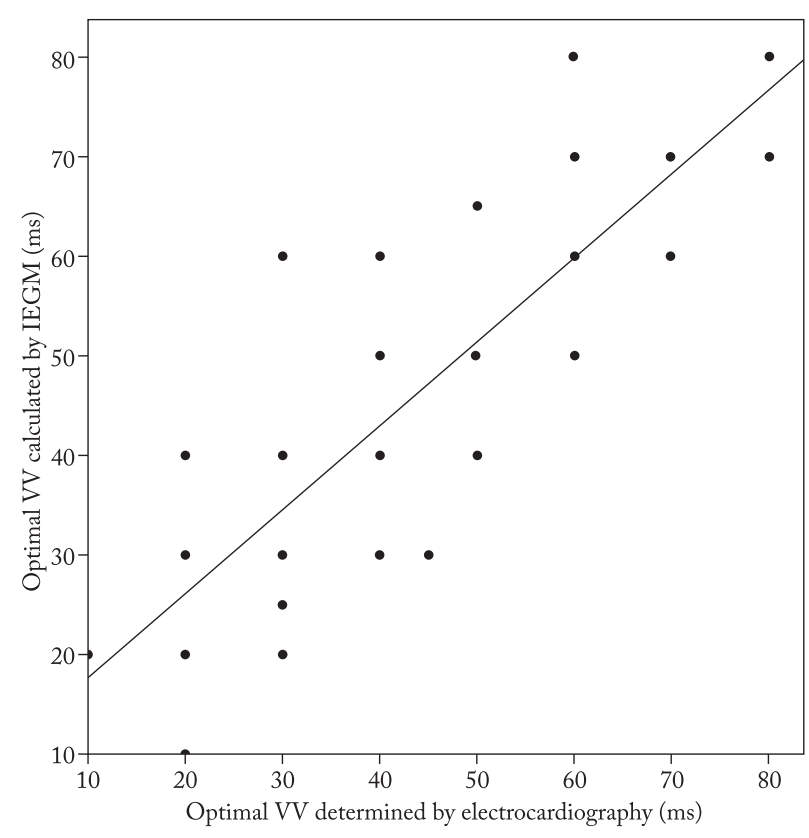

Fig. 2. Correlation between optimal interventricular delay $(V V)$ determined by echocardiography and intracardiac electrogram method (IEGM).

Table 2. Difference in LVOT, SAV, PAV, optimal VV and time between ECHO and IEGM

\begin{tabular}{|l|l|l|l|}
\hline & ECHO & IEGM & $\mathrm{p}^{*}$ \\
\hline LVOT (cm) & $17.2(6.8-25.6)$ & $17.2(6.4-25.1)$ & 0.2432 \\
SAV (ms) & $100(70-120)$ & $100(90-120)$ & 0.0953 \\
PAV (ms) & $140(110-160)$ & $140(130-160)$ & 0.0953 \\
VV (ms) & $40(10-80)$ & $45(10-80)$ & 0.3613 \\
Time (min) & $40(35-60)$ & $20(10-28)$ & $<0.001$ \\
\hline
\end{tabular}

* Mann-Whitney test; LVOT = left ventricular outflow tract; SAV = sensed atrioventricular delay; $\mathrm{PAV}=$ paced atrioventricular delay; $\mathrm{VV}=$ interventricular delay; $\mathrm{ECHO}=$ echocardiography; IEGM = intracardiac electrogram method; data presented as median and interquartile range

ference in sensed atrioventricular interval (SAV), paced atrioventricular interval (PAV), VTI and VV values between echocardiography and IEGM. However, IEGM was significantly less time-consuming (Table 2). There was a strong correlation between VV values determined by echocardiography and IEGM $(\rho=0.823, p<0.001)$ (Fig. 2). We also found similar positive correlations between PAV and SAV values determined by echocardiography and IEGM, but this correlation was substantially weaker $(\rho=0.477$, $\mathrm{p}<0.001)$. 


\section{Discussion}

This prospective clinical trial of AV/PV and VV delay programming is the first one that compared manual IEGM based on St Jude's CRT (Quick Opt ${ }^{\mathrm{TM}}$ algorithm) pacemakers with standard echocardiography optimization method ${ }^{1,18,23,24}$. Our study is the first to show that manual IEGM can be used for VV optimization after CRT implantation, even for devices that do not have automated IEGM system. Previous studies have shown that IEGM is an accurate alternative to time-consuming echocardiography techniques for VV optimization ${ }^{14,18,23-25}$. St Jude's CRT devices have automated IEGM systems, which can accurately calculate AV and VV delay in one minute. However, Medtronic CRT devices do not provide automated IEGM system and therefore, echocardiography techniques are the only possibility for $\mathrm{AV}$ and $\mathrm{VV}$ optimization. Our study showed that IEGM could be manually applied using caliper in patients implanted with Medtronic CRT devices. Correlation coefficient between echocardiographic and IEGM determined VV interval was somewhat lower than in previous studies $(\mathrm{R}=0.823)^{1}$, but VTIs were exactly the same when VV interval was estimated with echocardiography or IEGM [17.2 (6.8-25.6) vs. 17.2 (6.4-25.1), $\mathrm{p}=0.243]$. Although manual IEGM takes a median of 20 (1028) minutes, which is substantially longer when compared with automated IEGM, it is still less time-consuming than echocardiography [40 (35-60) minutes]. Therefore, we can conclude that manual IEGM is a valuable option for AV and VV optimization. However, we suggest that automated IEGM system be implemented by all manufactures of CRT devices.

This study confirmed the efficacy of CRT in increasing EF of the left ventricle and decreasing both LVEDV and LVESV. These changes were even greater than reported in previous studies, since we enrolled only patients with substantial QRS prolongation, who obviously gain substantial benefit from CRT. Moreover, our study demonstrated that AV and VV optimization was necessary in patients undergoing CRT, and that further effort should be made in providing automated IEGM system by all CRT device manufacturers.

The main limitation of our study was the absence of long-term follow-up in patients undergoing CRT. Moreover, this was a non-randomized prospective study and thus, conclusions regarding diagnostic ac- curacy of manual IEGM should be interpreted with caution. However, our study provided a rationale for performing a randomized clinical trial that would compare long-term outcomes between patients in whom VV optimization performed with manual IEGM technique and by echocardiography.

In conclusion, our study indicated that manual IEGM could be good alternative to echocardiography and automated IEGM. It also emphasized the need for implementation of automated IEGM systems by all CRT device manufacturers in order to provide better understanding of conduction properties and optimal device programmed setting to get best cardiac function. The IEGM could also be an additional method providing faster ECHO optimization.

\section{References}

1. Baker JH, McKenzie J, Beau S, Greer GS, Porterfield J, Fedor $\mathrm{M}$, et al. Acute evaluation of programmer-guided AV/PV and VV delay optimization comparing an IEGM method and echocardiogram for cardiac resynchronization therapy in heart failure patients and dual-chamber ICD implants. J Cardiovasc Electrophysiol. 2007;8(2):185-91.

doi: 10.111/j.1540-8167.2006.00671.x

2. Jansen AHM, Bracke FA, van Dantzig JM, Meijer A, van der Voort PH, Aarnoudse W, et al. Correlation of echo-Doppler optimization of atrioventricular delay in cardiac resynchronization therapy with invasive hemodynamics in patients with heart failure secondary to ischemic or idiopathic dilated cardiomyopathy. Am J Cardiol [Internet]. 2006 Feb 15 [cited 2016 Oct 19];97(4):552-7. Available from: http://www.ncbi.nlm.nih.gov/ pubmed/16461055 doi: 10.1016/j.amjcard.2005.08.076

3. Bax JJ, Ansalone G, Breithardt OA, Derumeaux G, Leclercq C, Schalij MJ, et al. Echocardiographic evaluation of cardiac resynchronization therapy: ready for routine clinical use? A critical appraisal. J Am Coll Cardiol. 2004;44(1):1-9. doi: 10.1016/j.jacc.2004.02.055

4. Abraham WT, Fisher WG, Smith AL, Delurgio DB, Leon AR, Loh E, et al. Cardiac resynchronization in chronic heart failure. N Engl J Med [Internet]. 2002 Jun 13 [cited 2016 Sep 21];346(24):1845-53. Available from: http://www.nejm.org/doi/ abs/10.1056/NEJMoa013168 doi: 10.1056/NEJMoa013168

5. Cazeau S, Leclercq C, Lavergne T, Walker S, Varma C, Linde $\mathrm{C}$, et al. Effects of multisite biventricular pacing in patients with heart failure and intraventricular conduction delay. $\mathrm{N}$ Engl J Med [Internet]. 2001 Mar 22 [cited 2016 Nov 28];344(12):873-80. Available from: http://www.nejm.org/ doi/abs/10.1056/NEJM200103223441202

6. Yu C-M, Wing-Hong Fung J, Zhang Q, Sanderson JE. Understanding nonresponders of cardiac resynchronization therapy current and future perspectives. J Cardiovasc Electrophysiol [In- 
ternet]. 2005 Oct [cited 2016 Oct 24];16(10):1117-24. Available from: http://www.ncbi.nlm.nih.gov/pubmed/16191124 doi: 10.1111/j. 1540-8167.2005.40829.x

7. Sogaard P, Egeblad H, Pedersen AK, Kim WY, Kristensen BØ, Hansen PS, et al. Sequential versus simultaneous biventricular resynchronization for severe heart failure. Circulation. 2002; 106(16): 2078-84.

8. Vanderheyden M, De Backer T, Rivero-Ayerza M, Geelen P, Bartunek J, Verstreken S, et al. Tailored echocardiographic interventricular delay programming further optimizes left ventricular performance after cardiac resynchronization therapy. Heart Rhythm [Internet]. 2005 Oct [cited 2016 Oct 25]; 2(10):1066-72. Available from: http://www.ncbi.nlm.nih.gov/ pubmed/16188583 doi: 10.1111/j.1540-8167.2005.40829.x

9. Meisner JS, McQueen DM, Ishida Y, Vetter HO, Bortolotti U, Strom JA, et al. Effects of timing of atrial systole on LV filling and mitral valve closure: computer and dog studies. Am J Physiol [Internet]. 1985 Sep [cited 2016 Oct 25];249(3 Pt 2):H604-19. Available from: http://www.ncbi.nlm.nih.gov/ pubmed/3839979

10. Porciani MC, Dondina C, Macioce R, Demarchi G, Pieragnoli P, Musilli N, et al. Echocardiographic examination of atrioventricular and interventricular delay optimization in cardiac resynchronization therapy. Am J Cardiol [Internet]. 2005 May 1 [cited 2016 Oct 27];95(9):1108-10. Available from: http://www.ncbi.nlm.nih.gov/pubmed/15842985

11. van Gelder BM, Bracke FA, Meijer A, Lakerveld LJM, Pijls NHJ. Effect of optimizing the VV interval on left ventricular contractility in cardiac resynchronization therapy. Am J Cardiol [Internet]. 2004 Jun 15 [cited 2016 Oct 27];93(12): 1500-3. Available from: http://www.ncbi.nlm.nih.gov/pub$\mathrm{med} / 15194020$

12. Mortensen PT, Sogaard P, Mansour H, Ponsonaille J, Gras D, Lazarus A, et al. Sequential biventricular pacing: evaluation of safety and efficacy. Pacing Clin Electrophysiol [Internet]. 2004 Mar [cited 2016 Nov 29];27(3):339-45. Available from: http: //www.ncbi.nlm.nih.gov/pubmed/15009860

13. Valzania C, Eriksson MJ, Boriani G, Gadler F. Cardiac resynchronization therapy during rest and exercise: comparison of two optimization methods. Europace. 2008;10(10):1161-9. doi: 10.1093/europace/eun216. Epub 2008 Aug 27.

14. Anselmino M, Antolini M, Amellone C, Piovano E, Massa R, Trevi GP. Optimization of cardiac resynchronization therapy: echocardiographic vs semiautomatic device algorithms. Congest Hear Fail. 2009;15(1):14-8. doi: 10 1111/j. 1751-7133.2008.00036.x.

15. Brignole M, Auricchio A, Baron-Esquivias G, Bordachar P, Boriani G, Breithardt OA, et al. 2013 ESC Guidelines on cardiac pacing and cardiac resynchronization therapy. Eur Heart J. 2013;15(8):1070-118.

16. Kamdar R, Frain E, Warburton F, Richmond L, Mullan V, Berriman $\mathrm{T}$, et al. A prospective comparison of echocardiography and device algorithms for atrioventricular and interventricular interval optimization in cardiac resynchronization therapy. $\mathrm{Eu}-$ ropace. 2001;12(1):84-91. doi: 10.1093/europace/eup337.
17. Cheng CM, Huang JL, Wu TJ, Su CS, Pai HY, Liao MF, et al. Comparison of quick optimization of interventricular delay between simple methods: intracardiac electrogram and surface electrocardiogram after cardiac resynchronization therapy. Europace. 2012;14(9):1317-23.

doi: 10.1093/europace/eus/061

18. Min X, Meine M, Baker JH, Pires LA, Turk KT, Horn EM, et al. Estimation of the optimal VV delay by an IEGM-based method in cardiac resynchronization therapy. PACE - Pacing Clin Electrophysiol. 2007;30(Suppl 1):S19-22. doi: 10.111/j.1540-8159.2007.00597.x

19. Wei H, Dong-mei W, Lin C, Chao-feng S, Guo-sheng F, Yutang $\mathrm{W}$, et al. A prospective study to evaluate the efficacy of an intracardiac electrogram-based atrioventricular and interventricular intervals optimization method in cardiac resynchronization therapy. Chin Med J. 2012;125(3):428-33.

20. Whinnett ZI, R Davies JE, Willson K, Manisty CH, Chow AW, Foale RA, et al. Haemodynamic effects of changes in atrioventricular and interventricular delay in cardiac resynchronisation therapy show a consistent pattern: analysis of shape, magnitude and relative importance of atrioventricular and interventricular delay. Heart. 2006;92:1628-34.

21. Ritter P, Padeletti L, Gillio-Meina L, Gaggini G. Determination of the optimal atrioventricular delay in DDD pacing. Comparison between echo and peak endocardial acceleration measurements. Europace [Internet]. 1999 Apr [cited 2016 Oct 19];1(2):126-30. Available from: http://www.ncbi.nlm.nih. gov/pubmed/11228855 doi:10.1053/eupc.1998.0032

22. Kindermann M, Fröhlig G, Doerr T, Schieffer H. Optimizing the AV delay in DDD pacemaker patients with high degree AV block: mitral valve Doppler versus impedance cardiography. Pacing Clin Electrophysiol [Internet]. 1997 Oct [cited 2016 Oct 19];20(10 Pt 1):2453-62. Available from: http://www. ncbi.nlm.nih.gov/pubmed/9358487

23. Porciani MC, Rao CM, Mochi M, Cappelli F, Bongiorno G, Perini AP, et al. A real-time three-dimensional echocardiographic validation of an intracardiac electrogram-based method for optimizing cardiac resynchronization therapy. PACE Pacing Clin Electrophysiol. 2008;31(1):56-63. doi: 10.1111/j. 1540-8159.2007.00925.x.

24. Reinsch N, Buhr C, Huptas S, Buck T, Konorza T, Wieneke H, et al. Reliability of a novel intracardiac electrogram method for $\mathrm{AV}$ and VV delay optimization and comparability to echocardiography procedure for determining optimal conduction delays in CRT patients. Indian Pacing Electrophysiol J.2009; 9(2):91-101. Available from: www.ipej.org

25. Giammaria M, Quirino G, Cecchi E, Senatore G, Pistelli P, Bocchiardo $\mathrm{M}$, et al. Comparison between IEGM-based approach and echocardiography in AV/PV and VV delay optimization in CRT-D recipients (Quicksept study). Indian Pacing Electrophysiol J. 2016;16(2):59-65. doi: 10.1016/j.iepj.2016.05.001. 
Sažetak

\title{
PRIMJENA RUČNE METODE INTRAKRDIJALNIH ELEKTROGRAMA ODGOVARAJUĆA JE ZAMJENA EHOKARDIOGRAFSKOJ ATRIOVENTRIKULSKOJ I INTERVENTRIKULSKOJ OPTIMIZACIJI RESINKRONIZACIJSKOGA ELEKTROSTIMULATORA SRCA
}

\author{
B. Pezo Nikolić, D. Lovrić, J. Ljubas Maček, V. Rešković Lukšić, R. Matasić i J. Šeparović Hanževački
}

Neki proizvođači nemaju automatski sustav intrakardijalnog elektrokardiograma (IEGM) za atrioventrikulsku (AV) i interventrikulsku (VV) optimizaciju u srčanoj resinkronizacijskoj terapiji (CRT). Cilj ovoga istraživanja bio je procijeniti točnost ručnog namještanja IEGM kod bolesnika s ugrađenom CRT. U istraživanje je bilo uključeno 48 bolesnika kojima je prethodno ugrađen Medtronic Syncra CRT. Jedan mjesec nakon ugradnje svim bolesnicima je učinjena standardna kontrola elektrostimulatora, nakon čega je učinjena optimizacija CRT, prvo metodom IEGM, a potom ultrazvučno. Srednja dob bolesnika bila je 60,7 $\pm 11,8$ godina; bila su $33(68,8 \%)$ muškarca. Nakon ugradnje CRT, ejekcijska frakcija lijeve klijetke narasla je s $28,0 \pm 7,9 \%$ na $39,1 \pm 11,0 \%$ ( $<<0,001$ ). Najveći integral brzine protoka nad aortnom valvulom (aVTI) dobiven je pri VV intervalu od 20-50 ms lijeve preekscitacije. Utvrđena je snažna korelacija između trajanja VV intervala dobivenog ultrazvučno i IEGM $(\mathrm{R}=0,823, \mathrm{p}<0,001)$. Nismo našli statistički značajnu razliku između vrijednosti $\mathrm{AV}, \mathrm{VV}$ i aVTI dobivenih ultrazvučno i metodom IEGM. Ipak, metoda IEGM zahtijeva bitno manje vremena od ultrazvučne metode [20 (10-28) prema 40 (35- 60) minuta, p<0,001]. Naše istraživanje pokazuje da ručna metoda IEGM može biti dobra alternativa ehokardiografskoj optimizaciji i automatskoj metodi IEGM. Također ukazuje na potrebu omogućavanja automatske IEGM optimizacije kod što više CRT uređaja.

Ključne riječi: Intrakardijalni elektrogram; Optimizacija; Srčana resinkronizacijska terapija; Atrioventrikulski interval; Interventrikulski interval 